\title{
Europe and North East Asia, a complementary couple?
}

\author{
György Széll
}

Correspondence: gszell@uos.de University of Osnabrueck, School of Cultural \& Social Sciences, D-49069

Osnabrueck, Germany

\section{Springer}

\begin{abstract}
s
European and North East Asian histories are intermingled since more than 200 years - full of conflicts, but also of cooperation. An issue over the past couple of decades is about European, Asian or universal values. The article confronts these different approaches and comes to the conclusion that diversity and complexity ask for a multidisciplinary approach.

Die europäische und nordostasiatische Geschichte vermengen sich seit mehr als zweitausend Jahren. - voller Konflikte, aber auch Zusammenarbeit. Ein besonderes Problem ist die Frage nach europäischen, asiatischen oder universellen Werten. Der Beitrag stellt diese verschiedenen Ansätze gegenüber und kommt zu dem Ergebnis, dass Vielfalt und Komplexität einen multi-disiziplinären Ansatz erfordern.
\end{abstract}

Keywords: Europe, North East Asia, USA, Culture, Values, Anti-communism, Communism, Globalisation, History, Crisis

"The idea of progress is to be founded in the idea of catastrophe.

That it goes 'on as such', is the catastrophe.

It is not each coming, but each given."

(Walter Benjamin, written between 1937 and 1940)

\section{Introduction}

Is it possible to compare values and cultures with each other? Are not all cultures and therefore their values - like all individuals too - unique? (Vinken et al. 2004) If it was like that, we could only give descriptions but no explanations for differences, however, neither convergences. I characterize this procedure as 'Historicism'. Within Historicism the uniqueness of each phenomenon is postulated, so that a comparison is not given (Wikipedia 2015). Nevertheless there are comparative studies on value systems since a number of decades. They are often based on the value pyramid by the US-American Abraham H. Maslow (1954). This value pyramid assumes that humanity develops itself from the satisfaction of basic needs in five steps to immaterial values.

Another US-American, Ronald Inglehart, produced in a number of studies an index to compare value systems since the 1970s (1977, 1997; Inglehart and Welzel 2005). A Dutch, Geert Hofstede, researched an international comparison of corporate cultures with some 116,000 persons in 46 countries in the 1980s, which has been enlarged in the meantime up to 93 countries. Initially he used four criteria:

(c) 2016 The Author(s). Open Access This article is distributed under the terms of the Creative Commons Attribution 4.0 International License (http://creativecommons.org/licenses/by/4.0/, which permits unrestricted use, distribution, and reproduction in any medium, provided you give appropriate credit to the original author(s) and the source, provide a link to the Creative Commons license, and indicate if changes were made. 
- Power Distance (PDI)

- Individualism versus Collectivism (IDV)

- Masculinity versus Femininity (MAS)

- Uncertainty Avoidance (UAI).

Later on with the help of his collaborators another two criteria were added: LongTerm Orientation (LTO) and Indulgence versus Restraint (IVR) (Hofstede et al. 2010). A comparison, e.g. between Germany and the USA, brought the result that in the USA a much higher individualism and much less Uncertainty Avoidance prevailed than in Germany <https://www.geert-hofstede.com>.

For our further consideration I propose the following three axioms as a necessary precondition for all theoretically guided analyses:

- Historicity,

- materialism and

- dialectics (Széll 1972).

The interest of all studies within social sciences lies in my opinion in the explanation of the specific. How do we explain differences between different societies and cultures, not only between continents, i.e. large regions but also within these large regions, down to the smallest political, social, economic, cultural units, the village, the company ...? Karl Marx explains it like this:

"It would seem to be the proper thing to start with the real and concrete elements, with the actual preconditions, e.g., to start in the sphere of economy with population, which forms the basis and the subject of the whole social process of production. Closer consideration shows, however, that this is wrong. Population is an abstraction if, for instance, one disregards the classes of which it is composed. These classes in turn remain empty terms if one does not know the factors on which they depend, e.g., wagelabour, capital, and so on. These presuppose exchange, division of labour, prices, etc. For example, capital is nothing without wage-labour, without value, money, price, etc. If one were to take population as the point of departure, it would be a very vague notion of a complex whole and through closer definition one would arrive analytically at increasingly simple concepts; from imaginary concrete terms one would move to more and more tenuous abstractions until one reached the simplest definitions. From there it would be necessary to make the journey again in the opposite direction until one arrived once more at the concept of population, which is this time not a vague notion of a whole, but a totality comprising many determinations and relations. The first course is the historical one taken by political economy at its inception. The seventeenthcentury economists, for example, always took as their starting point the living organism, the population, the nation, the State, several States, etc., but analysis led them always in the end to the discovery of a few decisive abstract, general relations, such as division of labour, money, and value. When these separate factors were more or less clearly deduced and established, economic systems were evolved which from simple concepts, such as labour, division of labour, demand, exchange-value, advanced to categories like State, international exchange and world market. The latter is obviously the 
correct scientific method. The concrete concept is concrete because it is a synthesis of many definitions, thus representing the unity of diverse aspects. It appears therefore in reasoning as a summing-up, a result, and not as the starting point, although it is the real point of origin, and thus also the point of origin of perception and imagination. The first procedure attenuates meaningful images to abstract definitions, the second leads from abstract definitions by way of reasoning to the reproduction of the concrete situation." (Marx 1973, originally 1859)

Following these reflections Marx wrote about the oscillation between the abstract, the general and the concrete, the specific (Marx 1976, 2011). The driving interest within the Humanities and the social sciences concerns - in contrast to the natural sciences - the explanation of the concrete, the societal and cultural specificities. But also why there are varieties and differences. A special challenge lies in the comparison between Europe and North East Asia.

Formally Europe reaches from the Atlantic Ocean to the Ural, however, actually Europe and Asia is a single continent: Eurasia. Over thousands of years relations between North East Asia and Europe are coined by competition, conflicts but also by cooperation. Already between the Roman and the Chinese Empires regular exchanges happened - mostly via the Silk Road (Böckelmann 1998). Especially the Venetian Marco Polo stands for this kind of exchange in the $13^{\text {th }}$ century (Münkler 1998). Djingis Khan symbolizes a more violent relationship between these two world regions nearly at the same period (Wikipedia 2012a).

If I speak of East Asia, so I will first of all concentrate myself on North East Asia, because South East Asia is largely culturally quite different. North East Asia encloses besides China - including Taiwan and Hong Kong, but in principle also Singapore Japan as well as both Koreas.

Its great distance historically characterizes especially the relationship between Europe and Korea - not only geographically, but also culturally. The Korean kingdom and its short-lived Empire were called the ,Hermit Kingdom'. Korea secluded itself from the rest of the world even longer than China and Japan (Eggert and Plassen 2005).

\section{Theses}

- Each culture produces its value system. These different cultures are coined through varied history.

- To understand society the consideration of their deep structures is essential. (Gurvitch 1971)

- Nevertheless the risk of culturalism exists, i.e. that all social, political and economic structures are reduced to cultural differences (Burger 2011).

- But there are as well anthropological constancies and with them values. At the same time nearly all cultures are the result of intercultural exchange - sometimes peacefully, often violently (Huntington 1996).

- Innovation - in each sector of society, whether within culture, arts, science, and politics - only develops via intercultural exchange.

- 1968 meant for the whole of Europe - in contrast to the USA and also Asia or Latin America - a fundamental moment of cultural, political and social change in the long run (Széll 2009). 


\section{Historical background of Europe}

The capitalistic revolution in Europe combined with the development of science and technology led since the $15^{\text {th }}$ until the middle of the $20^{\text {th }}$ century to its predominance - including its colonies over the rest of the world. (Braudel 1992; Wallerstein 1974-1989, 2004; Weber 1904) The basis for this predominance was - according to Max Weber - the religious value system of North Western Europe, its protestant ethics (Weber 1978). The West exploited the globe - due to its economic, technological and military superiority. Only four countries were not fully colonized: Japan, Korea, Yemen and Ethiopia. The result of this European hegemony is Eurocentrism.

For modern Europe the Westphalian Peace Treaty in 1648, which constituted the modern international law, was an epochal event. It contributed to tolerance, religious freedom und peace for nearly 150 years. The incarnation of European values is the Enlightenment. Already at the beginning of the $18^{\text {th }}$ century Abbe de Saint Pierre argued for a 'European Union'. However, it took more than two and half centuries and many wars, including two World Wars, to reach this goal (Walther 2012).

The development model of all late nations is the one of ,defensive modernization'(Wehler 1978-2008). Germany was the first to practice it, why it is often characterized as ,German Sonderweg, although the development of England was the exception. Defensive modernization means authoritarian modernization top-down, as practiced by the first German chancellor Bismarck in the last third of the $19^{\text {th }}$ century (Széll 2001a). That is market economy without democracy (Hwang 1989). Today this is called 'Peking consensus' instead of 'Washington consensus'.

Europe was thrown back - due to its two World Wars, started by Germany for decades in its political, economic, social and cultural development (Széll 2011b). Since then, thanks to the reconciliation of all those involved, it realized the longest peace period in its history (Buruma 1994; Széll 2009). ${ }^{1}$ For that reason the EU received the Peace Nobel Prize in 2012. In consequence European nations have reached the highest quality of life and working life (Széll and Széll 2009; World Bank 1992ff). However, Europe is still looking for its identity (Széll and Ehlert 2001; Wagner 2006). Nevertheless the European Union is - after the failure of the Soviet Union - the biggest and most successful political, economic, cultural and social experiment in modern history (European Union 2004). How the $21^{\text {st }}$ century will go, we cannot yet know (Farnen 2004; Széll 2002).

\section{The crisis}

Crises characterize capitalism from its very beginning (cf. especially on this point Joseph Schumpeter's ,creative destruction', 1967). The German economic miracle as well as the ,Trente Glorieuses' in France after World War Two are the exceptions from the rule over the last two centuries (Lutz 1984). Insofar is the on-going worldwide economic and financial crisis the normality.

The European Union is first of all a political project after World War Two - and also before, namely after World War One (Széll et al. 2009). However, we are still far away from a political and social union. Perhaps is the recent crisis a driving moment, as also the implosion of the Soviet Empire, to fasten this process - but it may also lead to the contrary, as we see in England. 
The dominance of capitalist relations of production has brought so far in principle only an economic and partly a currency union. And capital has no home country! Therefor Social Europe leaves much to desire (Arbeitsgruppe Alternative Wirtschaftspolitik 2012; Busch et al. 2000; Kim and Széll 2011; Széll 2002, 2007). The worldwide financial and economic crisis hit a number of European countries, especially in the South, quite hard. Most of them managed to overcome the crisis over the last couple of years. Only Greece so far was not so successful, which is related mostly to its own structural problems in many areas, but also the strategy by the European institutions and the International Monetary Fund came too late and was not always adapted. Nevertheless it is an indicator of the lack of a common economic and financial policy, and finally the unaccomplished political union. Many Europeans therefore argue for more integration, whereas at the same time Euro scepticism is increasing.

\section{What are European values?}

The European half-continent is largely formed by its antiquity, as well by monotheism, which was introduced from the Near East. Actually the heritage of the antiquity was rediscovered during the period of the Renaissance via the Arab culture, because it was largely forgotten in Europe itself. Besides there remain quite a few other cultural relics from preantique and pre-Christian periods, e.g. the Germanic, Celtic, Slavic cultures etc.

Due to this heritage Europe is largely determined by a black-and-white thinking, through a sin complex, whereas in North East Asia a shame culture prevails (Böckelmann 1998; Singer 1990). But which Europe? Western, Northern, Central, Eastern or Southern Europe? Greater Europe with its 47 nations? The European Union with its now 28 Member States? Negotiations with six further nations are in progress, amongst them Turkey. Eurozone? At the moment 19 members only, although in principle all EU-members should join the Euro.

Since the $19^{\text {th }}$ century thanks to a strong labour movement most European nations realized a welfare state - be it in a capitalist or socialist variety (Széll 2013c). In the reconstruction period after World War Two foremost in the Netherlands, in Germany and Austria a kind of 'trustful cooperation' between capital, labour and the State emerged, which has been designated as ,corporatism' (Fürstenberg 2006; Van Waarden 1992). The German model of social partnership within a 'Social Market Economy' serves as ideal type. (Mesch 1995; Széll 2008b) Similarly labour relations in North East Asia - in contrast to the U.S.A. - are partly based on trust and mostly not any more on class struggle, however still on power relations between management and unions, characterized by coercion and oppression (Die Europäischen Werte 2012; Széll 2011a).

Europe is proud of its diversity. So, e.g. we have Roman, Germanic, Anglo-Saxon, Slavic cultures and legal systems. Not only the religious denominations but also the deep structures have a great diversity and produced a large variety of cultures, value systems as well as languages (Joas and Wiegandt 2010). Europe's borders are floating (Széll 1996). The West in the global context comprises the former European colonies - including Latin America. And Islam is part of the European culture since several centuries.

"Asked which values represent best the EU, in autumn 2010 at a Eurobarometer survey $38 \%$ of surveyed answered responded 'human rights' as well as 'democracy'. $35 \%$ choose 'peace'. The following values were 'state of law' (25\%), 'solidarity' (20\%), 
'respect of other cultures' (18\%) as well as 'respect of human life' (14\%). The values 'equality', 'freedom of the individual, 'tolerance,'self-realization' and 'religion' were for less than one seventh of the population of the 27 EU-member states part of the three values, which represent best the EU. "(Bundeszentrale für politische Bildung 2012; translation by Gy.Sz.) (Fig. 1).

\section{But are they not universal values?}

"The European Union is a community of values, so we hear nearly every day from politicians, and the values, on which the EU is based, are the European ones. But is this actually right? The geographical Europe, the Europe from the Atlantic to the Ural, was never a community of values. Large parts of Europe had no part in the development of values, on which the EU refers to. Vice-versa the values, to which the USA, Canada, Australia, New Zealand and the state of Israel adhere to, are no others than those, which we like to call »European«.... We should therefore not to speak of European, but of Western values, when it is about the basis of our democracy and the coherence of the European Union. "(Winkler 2007; translation by Gy.Sz.)

Winkler relates the specific development in Western and Central Europe to their dominant dualism and later pluralism. Montesquieu's principle of separation of power

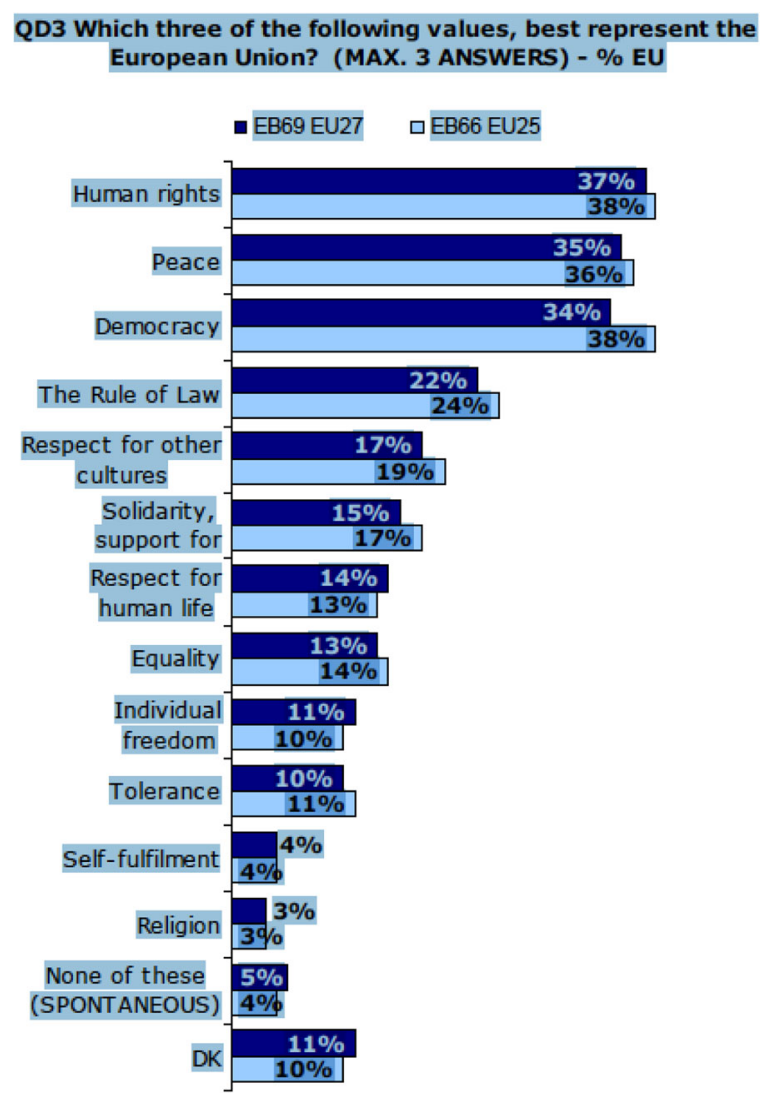

Fig. 1 Values in the European Union (TNS Opinion \& Social 2012) 
remains until now the base. In the French revolution of 1789 the universal human rights were for the first time formulated and voted by the Convent. They became law:

"Article 1: Men are born and remain free and equal in rights. Social distinctions may be based only on considerations of the common good.

Article 2: The aim of every political association is the preservation of the natural and imprescriptible rights of Man. These rights are Liberty, Property, Safety and Resistance to Oppression" (Fig. 2).

The three main values - „Freedom, Equality, Fraternity“- are carved in stone on all public buildings in France. All further revolutions are inspired by this declaration since

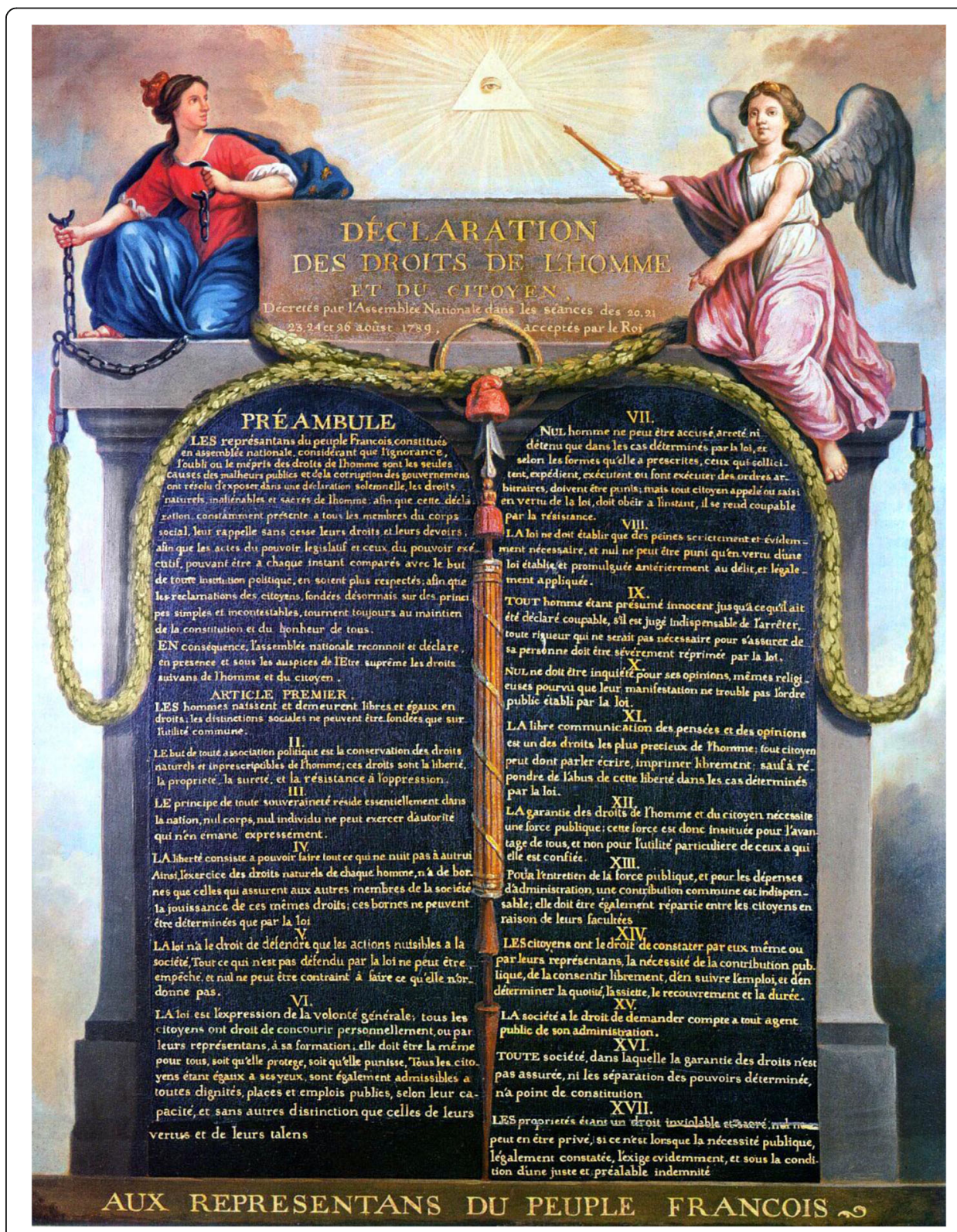

Fig. 2 Universal Declaration of Human Rights 
then. Based on this French and European tradition the General Declaration of Human Rights was voted by the United Nations after the terrible Second World War, of which the United Nations themselves are one its out-comings (Resolution 217 A (III) of the General Assembly on 10 December 1948). ${ }^{2}$ Probably European values are best summarized in the preamble to the European Constitution from 2004:

„Drawing inspiration from the cultural, religious and humanist inheritance of Europe, from which have developed the universal values of the inviolable and inalienable rights of the human person, freedom, democracy, equality and the rule of law,

Believing that Europe, reunited after bitter experiences, intends to continue along the path of civilisation, progress and prosperity, for the good of all its inhabitants, including the weakest and most deprived; that it wishes to remain a continent open to culture, learning and social progress; and that it wishes to deepen the democratic and transparent nature of its public life, and to strive for peace, justice and solidarity throughout the world,

Convinced that, while remaining proud of their own national identities and history, the peoples of Europe are determined to transcend their former divisions and, united ever more closely, to forge a common destiny,

Convinced that, thus 'United in diversity', Europe offers them the best chance of pursuing, with due regard for the rights of each individual and in awareness of their responsibilities towards future generations and the Earth, the great venture which makes of it a special area of human hope."

\section{US-American values? ${ }^{3}$ Western values? Universal values?}

If one speaks of ,European' values, so it is quite often in contrast to US-American values. Whereas in the USA the tendency goes to refer to 'Western community of values', respectively to universal values, where subliminally the US-American interpretation as the only valid and correct one is to be understood. In the preamble to the Declaration of Independence from 1776 we can read:

»We hold these truths to be self-evident, that all men are created equal, that they are endowed by their Creator with certain unalienable Rights, that among these are Life, Liberty and the pursuit of Happiness.«

Probably Marxism in its diverse forms has had the biggest impact not only within all of Europe and the rest of the world, but especially in North-East Asia, where several countries - namely China, the most populous country in the world, i.e. every fifth human being, North Korea, Vietnam and Laos are until now ruled by communist parties. And even Japan is regarded as the only country, "where communism works". (Kenrick 1988) Insofar Maoism can be regarded as a collateral damage of European-Asian interaction (1961-1977). In the 1960s the Cultural Revolution fired back on Europe with a large number of Maoist groups and parties. How far Maoism will survive in the $21^{\text {st }}$ century remains an open question. 
Interestingly we spoke during the period of Cold War of 'Western' values to differentiate them from the Soviet Union and other socialist countries and demonstrate the own superiority (Széll and Kim 2015). In this phase, as before, the USA regarded the defence of human rights quite selectively: Only when it convened to their military-economic interests, they defended them (Baran and Sweezy 1967; Hardt and Negri 2000). Otherwise dictatorships were not only tolerated but quite often installed (Chile, Brazil etc.) Insofar the late US-American sociologist Bertram Gross calls the US-American system 'friendly fascism' (1980). Also the German philosopher Robert Kurz in his 'Black Book Capitalism' (1999) a profound critique of the dominant relations of production, which cover not only Europe but the rest of the world too. However, we should mention in this context, that the book by Kurz was a response to the 'Black Book Communism' by Courtois et al. (1999).

The dominating neoliberalism seems to be the incarnation of US-American values. However, we should be careful: Friedrich August Hayek, the main protagonist, was a European, who already in the 1930s conceived the bases of neoliberalism (1948, 1952; Pies and Leschke 2003). The author, who is mostly cited today in this context, is the late Milton Friedman, professor at the University of Chicago and winner of the Prize in honour of Nobel for Economics, who propagated this approach first in the USA since the 1960s and then successfully worldwide (1982). In politics neoliberalism culminated as Thatcherism in the UK and as Reagonomics in the USA in the 1980s (Pierson 1994). It is worthwhile mentioning that first a European, i.e. British Prime Minister Margaret (Maggy) Thatcher, before the US-American president, Ronald Reagan, elevated neoliberalism as principle of economic policies.

On the other side it was the US-American president Franklin Delano Roosevelt, who as the first after the world economic crisis of 1929 practiced Keynesianism in the form of the 'New Deal' (Keynes 1936; Shlaes 2011). Insofar are US-American values - as mentioned above by Winkler - not clearly to be differentiated from European values. As mostly in life it is not a distinction 'either-or', but of gradual differences, which, however, may be quite marked (Herzinger 2002).

The biggest difference between Europe and the USA in regard to value systems concerns the role of religion (Norris and Ronald 2011). Although the USA foster pluralism of religion, nevertheless nearly everybody has to be a member of a religious community - similar to India - to be socially accepted and integrated, especially to make a political career. This phenomenon illustrates the limits of Enlightenment within the USA. The Pilgrim Fathers, who founded the US-American society in the $17^{\text {th }}$ century, determine since then its value system. Therefore - the election of the black Barack Obama as $44^{\text {th }}$ president - the WASP (White Anglo-Saxon Protestants) remain the dominant social class. And racism and xenophobia are still rather widespread. The French lawyer and politician Alexis de Tocqueville has in my eyes already in his book ,Democracy in America, written in 1835, delivered until today the best, valid analysis of the USAmerican society and its value system (1984; cf. also Széll 1985). This value system provides the legitimisation for the numerous military interventions by the USA since more than a century - although most of them failed (Széll 2010b).

Religious fundamentalism explains as well the role of evangelicals and of creationism, i.e. the negation of modern sciences. The evangelicals see their task in missionizing the whole world, to save it as well as themselves. They are rather successful over the last 
couple of decades, notably in Latin America and East Asia, especially in South Korea. Even the past South Korean president, Lee Myung-bak, is a very active Presbyterian. Within politics it is apparently not only about economic, political and military but at least also about cultural hegemony (Gramsci 2000).

\section{Anticommunism}

An important aspect for our consideration of US-American politics after World War Two, i.e. the so-called Cold War, is anticommunism, which culminated in McCarthyism in the 1950s (Defty 2004; Evans 2009). Via the dominance of the USA in the West anticommunism became in Western Germany as well in South Korea kind of core-ideology (Abendroth 1978; Thomas 2012; Song and Werning 2012). This ideology and its practice could build on existing anti-communist organisations and structures. Even social democrats in the F.R.G. supported anticommunism including Berufsverbote in the period of Peace Nobel Prize winner Chancellor Willy Brandt (Széll 2010c).

\section{North East Asia}

Already Karl Marx distinguished in his analysis of the development of relations of production the Asiatic mode of production from the European one (Wittfogel 1931; Dutschke 1974). This part of the world has at the moment the highest economic growth and the lowest birth rates. The economic success of North East Asia is mainly based on its culture and respective values. Education since always comes first in this region. South Korea has with more than $80 \%$ per year the highest rate of university alumni in the world. Without any doubt Confucianism, which is again allowed and even encouraged in China, plays an eminent role in this context, although there is an on-going debate about its real impact (Lee 2002, 2003, 2009; Weggel 1996).

Quality of life - with the exception of Japan - is in East Asia still below average. E.g. the region has the longest working hours and the highest suicide rates. Corporate Social Responsibility remains underperforming (Széll 2009). Is there a connection? China takes again the place in the world economy and politics today, which it had 200 years ago before the Europeans brought it into dependence (Snow 1994). The recent success is largely favoured by corruption and exploitation (migrant workers) and led to one of the most inegalitarian societies in the world (Schienstock et al. 1997; Széll 2010a).

\section{Are there North East Asian values?}

Is there an East Asian identity? (Buruma 1996; Pfennig 1995; Thompson 2001) Although China, Korea (Széll 2010c) and Japan (Inoue 2001; Széll 2001a) are quite different, they nevertheless share - similar to Europe - common cultural deep structures: In their case, as already mentioned namely Confucianism, Buddhism, and colonial experiences (Schmidt-Glintzer 2011; Singer 1990). For Japan we have to consider Shintoism, which was until 1945 the state religion (Lokowandt 2001). Finally we have to mention Shamanism as well, which remains present in Korea but also in parts of China including Taiwan and in Japan (Kim 2003). This world region is therefore - like Europe - impregnated by high cultures, several thousand years old - in contrast to the USA (Lee and Saaler 2003). The Chinese culture - with its influences from India - is the original culture of East Asia, which in contrast to Europe is characterized by its 


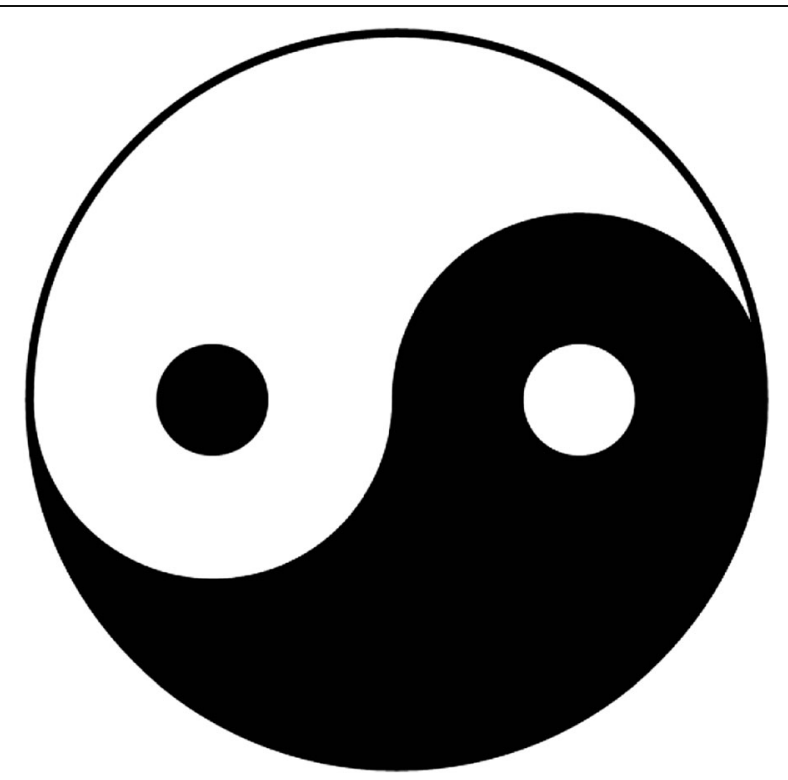

Fig. 3 Ying and Yang

complementarity. Yin and Yang - although also painted black and white - are a symbol for this complementarity (Fig. 3).

From this principle derives the necessity for tolerance (Ernst 2009). In these shame cultures harmony predominates over individual interests, on what even the Communist Party of China always insists (Coulmas 1993). The collective comes first. ${ }^{4}$ Seemingly North East Asia - in contrast to the West - is less ideological and more coined by pragmatism, although the term stems from liberal tradition in the U.S.A. (Nisbett 2005, pp. 120, 165 f., $174 \mathrm{ff}$.) That historical reality not always fits these fundamental principles is for sure certain.

What are now the specificities of both Koreas? Like Germany and Europe until a quarter century ago Korea is still divided, and much more than it was ever the case in Europe. This can be explained by the terrible Korean War between 1950 and 1953 on the one hand, and the lack of a peace treaty on the other hand. Not only North Korea is since decades a military dictatorship (Kim 1984), but this was also true for South Korea (Shim 2004; Shin 2005; Shin 2012; Werning 1988, 2002). And China remains de facto a military dictatorship and has not much in common with socialism. Also the rest of North East Asia (Japan, South Korea, Taiwan, Singapore) is still far away from well-functioning democracies (Croissant 2002; Széll 2008a). Inner societal contradictions and conflicts remain strong. South Korea continues to be deeply divided into two camps, down within the trade union movement.

The relatively short period of sunshine policies in South Korea following the German example by Kim Dae-Jung (1998-2003) and his (Kim 1994), tragically ended successor Roh Moo-Hyun (2003-2008) could not change the basic political structures, as could be seen by the two successive presidential elections (Song and Werning 2012).

The new capitalism of competition has produced in South Korea on the one hand an enormous economic boom and linked to it international big conglomerates (Samsung, Hyundai, shipbuilding, construction etc.) and enormous increase in higher education; on the other hand social conflicts and still the lowest percentage of foreigners - reminiscence of the Hermit Kingdom? The future of North East Asia and peace in the region is due to new nationalisms at risk (Ito 2001). So, the region is regarded - together with 
the Near and Middle East as one of the political and military hotspots with permanently increasing military spending and conflicts.

However, we should not forget that real existing socialism in Eastern Europe as well as military dictatorships in Southern Europe (Greece, Portugal, Spain) dominated as well their respective value systems - partly until today.

\section{Globalisation reconsidered}

A German proverb says: "One cannot live in peace, if the evil neighbour does not want it." Globalisation, which started in Europe in Early Modern Times, is now affecting most societies. The dominant relations of production are those of capitalism. Nonetheless we find substantial differences on all continents (Széll 2000). Europe changed in the meantime from main actor to victim. That reminds me of the poem ,sorcerer's apprentice' by von Goethe (1827):

"Lord and master, hear me crying! -

Ah, he comes excited.

Sir, my need is sore.

Spirits that I've cited

My commands ignore."

Due to the self-annihilation of Europe the USA became after 1945 the foremost and after the breakdown of the Soviet Empire - now the only remaining world power. The seemingly unstoppable rise of Japan in the 1980s ended abruptly with its financial crisis since the 1990s. The main reasons were corruption and speculation (Széll 2001a). In the meantime China is catching up with the USA, and it is only a matter of time, until it will overtake the USA in every regard. So, definitely it is not yet the end of history.

The new world order, which was proclaimed by the $41^{\text {st }}$ US-president George Bush Sr. in 1992, took quite another direction than planned. The OECD, the organisation, which associates the 34 richest industrial countries - which include meanwhile South Korea and other emerging economies - has been downgraded to a secondary institution. The G 7/8-nations and the UN Security Council - consisting of the USA, Russia, China, France and Great Britain - dominate in practice world politics, however, are permanently in quarrel. The emerging economies including South Korea have managed to enlarge the group to the G20. The reform of the UN Security Council is still blocked by the USA. So, the famous, HungarianUS-American speculator and philanthropist George Soros came to the conclusion that uncontrolled, global capitalism is a greater danger for freedom than Stalinism ever was (1998).

In the meantime concerning the value system corruption became a central indicator. The following table gives an overview, which has been established by the NGO Transparency International 2015. The survey included 175 countries (Table 1).

No surprise, that small, mainly (North-) European nations are at the top. However, the result may surprise in one point: Singapore performs even better than Germany and Japan. Does it mean that authoritarian rule is able to combat corruption efficiently? In comparison to other authoritarian regimes, it seems to be more the exception of the rule. And South Korea remains since a number of years at the modest $43^{\text {rd }}$ rank, 
Table 1 Transparency International, corruption index/Rank and Points

\begin{tabular}{|c|c|}
\hline 1 & Denmark 92 \\
\hline 2 & New Zealand 91 \\
\hline 3 & Finland 89 \\
\hline 4 & Sweden 87 \\
\hline 5 & Norway 86 \\
\hline 6 & Switzerland 86 \\
\hline 7 & Singapore 84 \\
\hline 8 & The Netherlands 83 \\
\hline 9 & Luxemburg 82 \\
\hline 10 & Canada 81 \\
\hline 11 & Australia 80 \\
\hline 12 & Germany 79 \\
\hline 13 & Iceland 79 \\
\hline 14 & United Kingdom 78 \\
\hline 15 & Japan 76 \\
\hline 15 & Belgium 76 \\
\hline 17 & Hong Kong 74 \\
\hline 17 & Barbados 74 \\
\hline 17 & Ireland 74 \\
\hline 17 & USA 74 \\
\hline 21 & Chile 73 \\
\hline 21 & Uruguay 73 \\
\hline 23 & Austria 72 \\
\hline 24 & Bahamas 71 \\
\hline 43 & Korea (South) 55 \\
\hline 100 & China 35 \\
\hline
\end{tabular}

whereas China decreased - from $75^{\text {th }}$ rank in 2012 to number 100 - in spite of its continuous anti-corruption campaigns.

\section{EU-North East Asia cooperation}

The decolonialisation process by Great Britain, France, the Netherlands and Portugal in East Asia were important steps for a peaceful cooperation and competition - although they are not always fair. The peaceful return of Hong Kong and Macau to China was such an example. Since numerous years a more or less successful cooperation exists between the EU and East Asia, so e.g. at the summit in 2010. Another example is the ASEAN-EU Business Summit 2012. And Free Trade Agreements - in spite of all their deficiencies - are a supplementary step. The Shanghai Organisation for Cooperation comprises Russia as an Asian and not as a European nation. The APEC (Asia Pacific Economic Cooperation) excludes Europe.

The European integration serves for many regions in the world in spite of its crisis as a model (Latin America, Mercosur, African Union, Arab Union; Kim 2009). So, since many years a currency union in North East Asia is proposed following the example of the Euro. Unfortunately this project is stopped due to the territorial and other conflicts. 
Nevertheless China started a new successful initiative in creating the Asian Infrastructure Investment Bank (AIIB) as a counterpart to the Western hegemony within the World Bank and the International Monetary Fund.

\section{Conclusions}

Is it possible to learn from each other? Because scientists are convinced of it, they meet each other during conferences, workshops etc. and promote exchange via cooperation. Through common experiences parallels can be established. But they also have to acknowledge fundamental differences: between aggressors and victims e.g.

The lack of resources was for Europe as well for North East Asia one of the main challenges for their respective modernisations. Already after the first so-called oil-crisis in 1973 the French created the slogan: We don't have petrol, but we have ideas! In the same vein the German Chancellor, Helmut Schmidt, declared that the future of the F.R.G. will be the export of knowledge, software/org ware instead of products. This is not completely true, as Germany realizes its trade surplus - the biggest in the world together with China - still mainly due to the second. And actually those countries with a relatively high percentage of industrial production performed best to overcome the ongoing global economic and financial crisis. This holds true for Germany as well as for North East Asia.

Since the end of the Korean War in South Korea - as in the rest of the world - USAmerican values prevail. Since 30 years shareholder-capitalism, better to say shareholderdictatorship, dominates the markets (Soros 1998). Against it Europe tries to oppose its stakeholder-democracy (Sünker et al. 2003; Széll 2013a). For that project we need innovations - not only technological and economic, but notably social and cultural ones. However, the future of a society within capitalism is decided within the economy. In this realm specific European values emerged and have been implemented during the past decades, which discern Europe largely from the USA: industrial democracy, codetermination, the social market economy, social partnership, the welfare state etc. (Széll 2006). The debate about economic democracy as well as the welfare state were even central topics during the presidential elections in South Korea in December 2012. Insofar reciprocal influences are given.

In the USA the 'Pacific Era' is propagated since many years. For many US-Americans the 'old continent' is dead, although the financial crises and nearly all imperialist wars since 1945 started by the USA and were lost.

Social and ecological modernisations are the targets for the survival of humanity. The most important capital for the future is education (Széll 1972, 2013b; Széll et al. 2008). That unites Europe and East Asia. Investments therein, however, are affected by brain drain, notably by the USA. Besides Europe and East Asia it is India, which delivers the largest contingents for this mental exploitation.

On the other side there is talk about the decline in values in modern societies: USAmerican modern mass culture emphasizes hedonism, materialism, drug consumption - although these phenomena can already be found in other civilizations as well, e.g. in the antiquity and also the $19^{\text {th }}$ century. Refined culture, arts and music are values, where humans are most happy - even more than with sex.

At the same time religious fundamentalism is re-emerging, based on traditional values or better their modern re-interpretation - being Christian, Muslim or Jewish. So, which role plays religion in this context as a value system? Religions are considered 
as immaterial value systems. This is certainly a short circuit: Religions served always to legitimate rule and power. The world religions were also always at the same time large businesses and in many societies they remain the largest owners of properties. In modern capitalism new religions and sects improved their marketing and commercialized their business professionally. Especially in South Korea some of the most successful sects emerged (e.g. the Moon sects).

European values for Korea and North East Asia in a 'global' $21^{\text {st }}$ century means therefore in my opinion a reorientation away from mainly US-American cultural hegemony (Gramsci 2000), towards more Enlightenment and humanism. Can European social integration be a model for social peace? (Busch et al. 2000; Széll et al. 2009) Could it serve to overcome the division of Korea? (Koschyk 2005; Leibfried 2012).

Fortunately values are changing (Klages 1993; Klages et al. 1992; Korean National Commission for UNESCO 2003; Meulemann 1996). And each value system is also a struggle about memory (Leggewie and Lang 2011). The Canadian psychologist Richard Nisbett dreams of a synthesis of Western and Eastern cultures (2005): Aristotle and Confucius; Bach und Pandori? (Fig. 4).

Probably Europe's biggest contribution for humanity was the Enlightenment, but is in danger (Széll 2001a). Therefore the late Neil Postman argued for a Second Enlightenment (1999).

"Friedrich Engels once said: "Bourgeois society stands at the crossroads, either transition to socialism or regression into barbarism." What does "regression into barbarism" mean to our lofty European civilization? Until now, we have all probably read and repeated

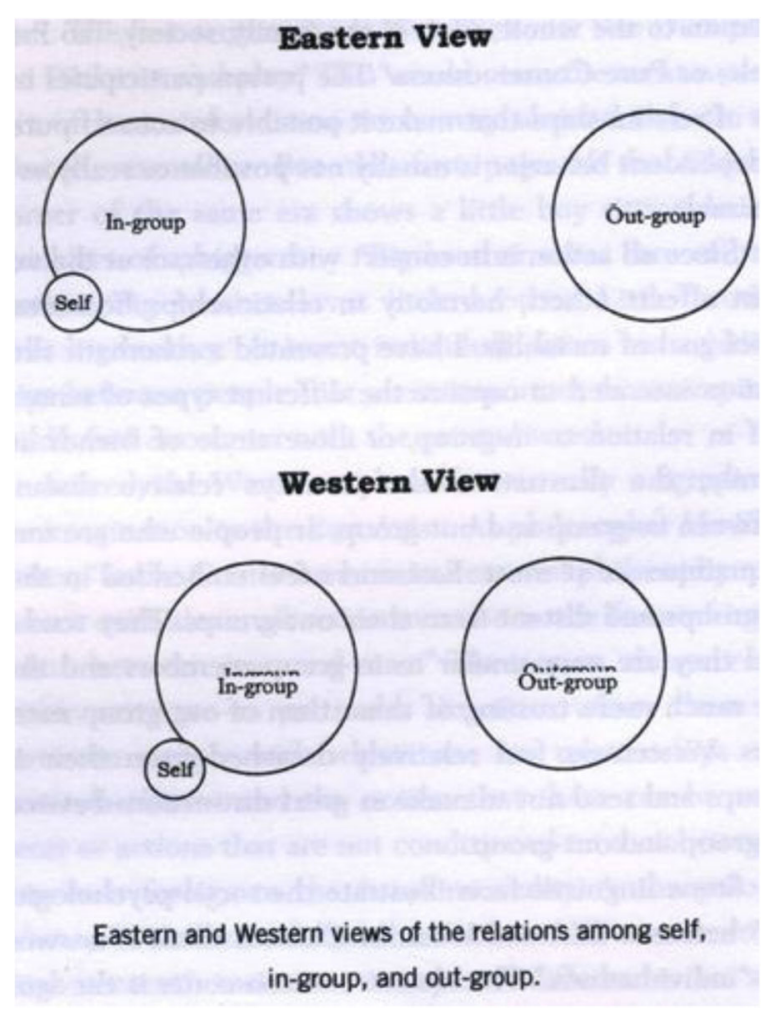

Fig. 4 East-West perspectives 
these words thoughtlessly, without suspecting their fearsome seriousness. A look around us at this moment shows what the regression of bourgeois society into barbarism means. This world war is a regression into barbarism. The triumph of imperialism leads to the annihilation of civilization. At first, this happens sporadically for the duration of a modern war, but then when the period of unlimited wars begins it progresses toward its inevitable consequences. Today, we face the choice exactly as Friedrich Engels foresaw it a generation ago: either the triumph of imperialism or the collapse of all civilization as in ancient Rome, depopulation, desolation, degeneration - a great cemetery. Or the victory of socialism, that means the conscious active struggle of the international proletariat against imperialism and its method of war. This is a dilemma of world history, an either/ or; the scales are wavering before the decision of the class-conscious proletariat. The future of civilization and humanity depends on whether or not the proletariat resolves manfully to throw its revolutionary broadsword into the scales. In this war imperialism has won. Its bloody sword of genocide has brutally tilted the scale toward the abyss of misery. The only compensation for all the misery and all the shame would be if we learn from the war how the proletariat can seize mastery of its own destiny and escape the role of the lackey to the ruling classes." (Luxemburg 1915, Chapter One)

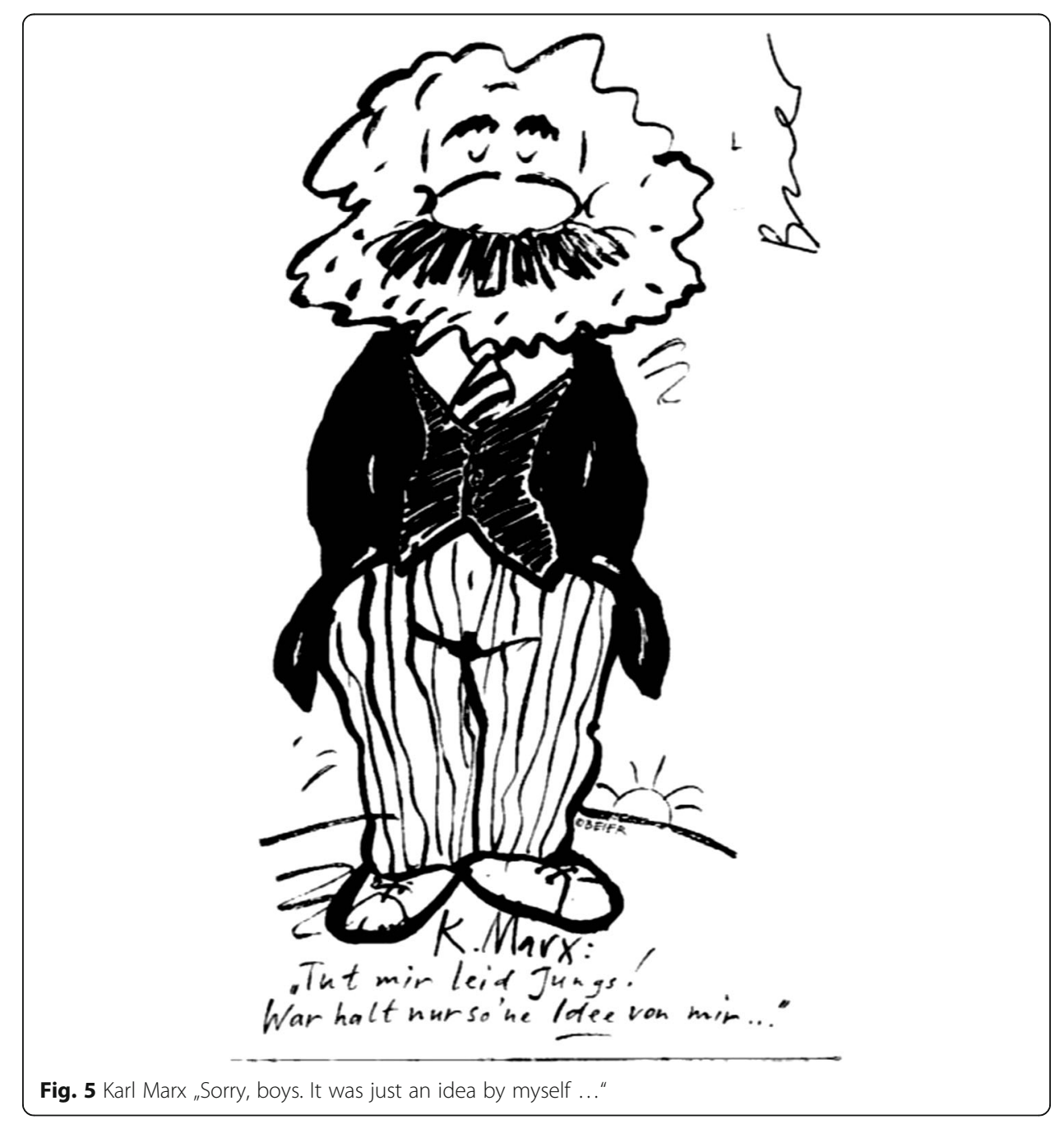


The outcome is open, everything depends on each of us. (Birnbaum 2001; Flechtheim 1978; Széll 2010a) Definitely we need more social innovations and not only technical ones (Harrisson et al. 2009) and a strong global civil society (Széll 2013c). Anyway the future of humanity will be decided in China - for better or for worse (Lorenz 2011; Széll 2010c) (Fig 5).

\section{Endnotes}

${ }^{1}$ Unfortunately the conflicts in the context of the dissolution of Yugoslavia, within Russia (Chechnya), and the aggression of Russia towards Georgia and Ukraine is harming this picture.

${ }^{2}$ So, it is certainly no hazard that this declaration was mainly formulated by a French, René Cassin.

${ }^{3}$ But we should beware of to speak of 'American' values, as the USA are not representative for the whole double-continent. Already Canada, especially French-speaking Québec, conducts quite different policies, which place it between the USA and Europe (Lesemann 2011; Schultze 1985; Wikipedia 2012b).

${ }^{4}$ Until modern times this actually also was true for Europe, and it was reintroduced by communism and fascism.

Received: 13 July 2015 Accepted: 12 August 2015

Published online: 24 June 2016

\section{References}

Abendroth, Wolfgang. 1978. Faschismus und Antikommunismus. Berlin/West: Argument-Verlag. Baran, Paul A., and Paul Sweezy. 1967. Monopoly Capitalism. New York: Monthly Review Press. Birnbaum, Norman. 2001. After Progress. The future of socialism. New York: Oxford University Press. Böckelmann, Frank. 1998. Die Gelben, die Schwarzen, die Weißen. Frankfurt a.M: Eichborn Verlag. Braudel, Fernand. 1992. Civilization and Capitalism 15 th $-18^{\text {th }}$ Century. Berkeley/CA: University of California Press. 3 vols. Bundeszentrale für politische Bildung. 2012. Europäische Werte.. http://www.bpb.de/nachschlagen/zahlen-und-fakten/ europa/70652/europaeische-werte. Accessed 6 Apr 2015.

Burger, Rudolf. 2011. Das Elend des Kulturalismus: Antihumanistische Interventionen. Essays. Springe: Zu Klampen. Buruma, lan. 1994. Erbschaft der Schuld. Reinbek: Rowohlt. Vergangenheitsbewältigung in Deutschland und Japan. Buruma, lan. 1996. Asiatische Werte? Zum Beispiel Singapur. Merkur 3: 189-203.

Busch, Klaus, et al. (eds.). 2000. Ways to Social Peace in Europe. Osnabrück: Secolo.

Coulmas, Florian. 1993. Japan: Gesellschaft mit beschränkter Haftung. Frankfurt a.M.: Campus. Das Land der rituellen Harmonie.

Courtois, Stéphane, et al. 1999. The Black Book of Communism: Crimes, Terror, Repression. Cambridge/MA: Harvard University Press.

Croissant, Aurel. 2002. Demokratische Entwicklung in Asien. Eine vergleichende Analyse defekter Demokratien in den Philippinen, Südkorea und Thailand. Wiesbaden: Westdeutscher Verlag.

Defty, Andrew. 2004. Britain, America and anti-communist propaganda 1945-1953: The information research department. London: Routledge.

Die Europäischen Werte. 2012. http://www.europaeischewerte.info.

Dutschke, Rudi. 1974. Versuch, Lenin auf die Füße zu stellen. Über den halbasiatischen und den westeuropäischen Weg zum Sozialismus. Berlin (West): Wagenbach.

Eggert, Marion, and Jörg Plassen. 2005. Kleine Geschichte Koreas. München: Beck.

Ernst, Sonja. 2009. Die Debatte um "asiatische Werte".. Rückblick und Bilanz, http://www.bpb.de/internationales/weltweit/ menschenrechte/38715/asiatische-werte?p=all. Accessed 6 Apr 2015.

European Union. 2004. Treaty Establishing a Constitution for Europe. Brussels: Official Journal of the European Union on 16 December 2004 (C series, No 310)

Evans, Stanton. 2009. Blacklisted by History: The Untold Story of Senator Joe McCarthy and His Fight against America's Enemies. New York: Three Rivers Press.

Farnen, Russell. 2004. Vor einer stürmischen Zukunft? Die USA und die EU im neuen Jahrtausend. Osnabrücker Jahrbuch Frieden und Wissenschaft 11: 176-190.

Flechtheim, Ossip K. 1978. Von Marx bis Kolakowski. Sozialismus oder Untergang in der Barbarei. Frankfurt a.M: EVA.

Fürstenberg, Friedrich. 2006. Welfare Corporatism in Transition: A German-Japanese Comparison. In Corporate Social Responsibility in the EU and Japan, ed. Széll György, 81-90. Frankfurt a.M: Peter Lang.

Gramsci, Antonio. 2000. The Antonio Gramsci Reader: Selected Writings, 1916-1935. New York: New York University Press.

Gross, Bertram. 1980. Friendly Fascism: The New Face of Power in America. New York: M. Evans.

Gurvitch, Georges (ed.). 1971. The social framework of knowledge. Oxford: Blackwell.

Hardt, Michael, and Antonio Negri. 2000. Empire. Cambridge/MA and London: Harvard University Press. 
Harrisson, Denis, György Széll, and Reynald Bourque (eds.). 2009. Social Innovation, the Social Economy and World Economic Development. Democracy and Labour Rights in an Era of Globalization. Frankfurt a.M: Peter Lang. Hayek, Friedrich. 1948. Individualism and Economic Order. Chicago: University of Chicago Press. Hayek, Friedrich. 1952. The Counter-Revolution of Science: Studies on the Abuse of Reason. Glencoe: Free Press. Herzinger, Richard. 2002. Was für den Westen zählt, oder: Sind amerikanische Werte auch unsere Werte? Aus Politik und Zeitgeschichte B 18: 3-6.

Hofstede Geert, H., Hofstede Gert Jan, and Minkov Michael. 2010. Cultures and Organizations: Software of the mind. Intercultural Cooperation and Its Importance for Survival, 3rd ed. New York: McGraw-Hill.

Huntington, Samuel P. 1996. The Clash of Civilizations and the Remaking of World Order. New York: Simon and Schuster. Hwang, Byung Duck. 1989. Nachholende Industrialisierung und autoritärer Staat. Das Beispiel Südkorea: Politik, Ideologie und weltmarktorientierter Kapitalismus. Berlin: Edition Sigma.

Inglehart, Ronald. 1977. The Silent Revolution. Changing Values and Political Styles among Western Publics. Princeton/NJ: Princeton University Press.

Inglehart, Ronald. 1997. Modernization and postmodernization: Cultural, economic, and political change in 43 societies. Princeton/N.J.: Princeton University Press.

Inglehart, Ronald, and Christian Welzel. 2005. Modernization, Cultural Change and Democracy. The Human Development Sequence. Cambridge: Cambridge University Press.

Inoue, Kiyoshi. 2001. Geschichte Japans, 3rd ed. Frankfurt a.M: Campus.

Ito, Narihiko. 2001. Japan und die friedliche Wiedervereinigung Koreas. Osnabrück: Universität Osnabrück, Forschungsstelle Japan. Schriften \# 14.

Joas, Hans, and Klaus Wiegandt (eds.). 2010. Die kulturellen Werte Europas. Frankfurt a.M: Fischer Taschenbuch Verlag.

Kenrick Douglas, Moore. 1988. Where Communism Works. The Success of Competitive Communism in Japan, 2nd ed,

1991. Rutland: Basingstoke Macmillan and Tokyo: C.E. Tuttle.

Keynes, John Meynard. 1936. The General Theory of Employment, Interest and Money. London: Macmillan.

Kim, Chongho. 2003. Korean Shamanism: The cultural paradox. Aldershot: Ashgate.

Kim, Dae-Jung. 1994. Is Culture Destiny? The Myth of Asia's Anti-Democratic Values. Foreign Affairs Nov./Dec.: 189-194.

Kim, Dschongho II. 1984. The Worker's Party of Korea is a Juche type revolutionary party which inherited the glorious traditions of the DIU. Pyongyang: [Reprint].

Kim, Nam-Kook (ed.). 2009. Globalization and Regional Integration in Europe and Asia. Ashgate: Farnham and Burlington.

Kim, Yongha, and György Széll (eds.). 2011. Economic Crisis and Social Integration. Frankfurt a.M: Peter Lang.

Klages, Helmut. 1993. Traditionsbruch als Herausforderung, Perspektiven der Wertewandelsgesellschaft. Frankfurt a.M. and New York: Campus.

Klages, Helmut, Hans-Jürgen Hippler, and Willi Herbert (eds.). 1992. Werte und Wandel. Ergebnisse und Methoden einer Forschungstradition. Frankfurt a.M: Campus.

Korean National Commission for UNESCO. 2003. Korean Anthropology: Contemporary Korean Culture in Flux. Seoul: Anthology of Korean Studies. vol. III.

Koschyk, Helmut (ed.). 2005. Deutschland, Korea - geteilt, vereint. München: Olzog.

Kurz, Robert. 1999. Schwarzbuch Kapitalismus. Ein Abgesang auf die Marktwirtschaft. Frankfurt a.M: Eichborn.

Lee, Eun-Jeung. 2002. Konfuzianismus und Kapitalismus. Markt und Herrschaft in Ostasien. Münster: Westfälisches Dampfboot.

Lee, Eun-Jeung. 2003. "Anti-Europa" - Die Geschichte der Rezeption des Konfuzianismus und der konfuzianischen Gesellschaft seit der frühen Aufklärung: Eine ideengeschichtliche Berücksichtigung der deutschen Entwicklung. Münster: LIT Verlag.

Lee, Eun-Jeung. 2009. "Confucian Culture"and Social Democracy in East Asia. In European Social Integration - A Model for East Asia? ed. Széll György, 255-274. Frankfurt a.M: Peter Lang.

Lee, Eun-Jeung, and Sven Saaler. 2003. Selbstbehauptungsdiskurse in Asien. China - Japan - Korea. München: iudicium.

Leggewie, Klaus, and Anne Lang. 2011. Der Kampf um die europäische Erinnerung. Ein Schlachtfeld wird besichtigt. Bonn: Bundeszentrale für politische Bildung.

Leibfried, Stephan. 2012. Vereinigung und die entwicklungspolitischen Perspektiven des Sozialstaats im Wahljahr 2012 Einige deutsche Eindrücke. Kultur Korea 4: 66-68.

Lesemann, Frédéric. 2011. Nouvelles fondations privées » et transition de «Régimes institutionnels. Lien Social et Politiques 65: 79-98.

Lokowandt, Ernst. 2001. Shinto: Eine Einführung. München: iudicium.

Lorenz, Andreas. 2011. Die asiatische Revolution. Wie der "Neue Osten"die Welt verändert. Bonn: Bundeszentrale für politische Bildung

Lutz, Burkhard. 1984. Der kurze Traum immerwährender Prosperität. Eine Neuinterpretation der industriell-kapitalistischen Entwicklung im Europa des 20. Jahrhunderts. Frankfurt a.M. and New York: Campus.

Luxemburg, Rosa. 1915. The Crisis of German Social Democracy (Junius Pamphlet).. https://www.marxists.org/archive/ luxemburg/1915/junius/ch01.htm. Accessed 6 Apr 2015.

Marx, Karl. 1859. 1993. Introduction. In Karl Marx, Contribution to the Critique of Political Economy. Moscow: Progress Publishers. https://www.marxists.org/archive/marx/works/1859/critique-pol-economy/appx1.htm\#205. Accessed 1 Apr 2015.

Marx, Karl. 1973. "Grundrisse". Foundations of the critique of political economy [1857-1858]. Harmondsworth. Penguin and London: New Left Review.

Marx, Karl. 1976. The Capital. Penguin: Harmondsworth. 3 vols. [1867].

Marx, Karl. 2011. The German Ideology. Eastford/CT: Martino Fine Books [1844].

Maslow, Abraham H. 1954. Motivation and personality. New York: Harper and Row.

Mesch, Michael (ed.). 1995. Sozialpartnerschaft und Arbeitsbeziehungen in Europa. Wien: Manzsche Verlags- und Universitätsbuchhandlung.

Meulemann, Heiner. 1996. Werte und Wertewandel. Zur Identität einer geteilten und wieder vereinten Nation. Weinheim and München: Juventa.

Münkler, Marina. 1998. Marco Polo: Leben und Legende. München: C.H. Beck. 
Nisbett, Richard E. 2005. The Geography of Thought - How Asians and Westerners Think Differently - and Why. London and Boston: Nicholas Brealey.

Norris, Pippa, and Inglehart Ronald. 2011. Sacred and Secular: Religion and Politics Worldwide. Cambridge: Cambridge University Press.

Pfennig, Werner. 1995. Asiatisierung und asiatische Werte: Positionen innerasiatischer Debatten. In Das neue Selbstbewußtsein in Asien. Eine Herausforderung? ed. Werner Draguhn and Günter Schucher, 58-76. Hamburg: Institut für Asienkunde.

Pierson, Paul. 1994. Dismantling the Welfare State? Reagan, Thatcher, and the Politics of Retrenchment. Cambridge: Cambridge University Press.

Pies, Ingo, and Martin Leschke (eds.). 2003. F.A. von Hayeks konstitutioneller Liberalismus. Tübingen: Mohr.

Postman, Neil. 1999. A Bridge to the Eighteenth Century. New York: Alfred Knopf.

Schienstock, Gerd, Paul Thompson, and Franz Traxler (eds.). 1997. Industrial Relations between Command and Market. A Comparative Analysis of Eastern Europe and China. New York: Nova.

Schmidt-Glintzer, Hedwig. 2011. Der Buddhismus. München: C.H. Beck.

Schultze, Rainer-Olaf. 1985. Das politische System Kanadas im Strukturvergleich. Studien zur politischen Repräsentation, Föderalismus und Gewerkschaftsbewegung. Bochum: Dr. A. Brockmeyer.

Schumpeter Joseph, A. 1967. The Theory of Economic Development, [1967]. Oxford: Oxford University Press.

Shim, HyunJu. 2004. Die Herausforderung der koreanischen Kultur durch die hegemoniale Globalisierung. Ein Beitrag zur Bestimmung des Verhältnisses intra-, supra- und transkultureller Werte. Frankfurt a.M. and London: IKO - Verlag für interkulturelle Kommunikation.

Shin, Jin-Wook. 2005. Modernisierung und Zivilgesellschaft in Südkorea. Zur Dynamik von Gewalt und Heiligkeit in der modernen Politik. Wiesbaden: Deutscher Universitäts-Verlag.

Shin, Kwang-Yeong. 2012. The Dilemmas of Korea's New Democracy in an Age of Neoliberal Globalisation. Third World Quarterly 33(2): 293-309.

Shlaes, Amity. 2011. Der vergessene Mann: Eine neue Sicht auf Roosevelt, den New Deal und den Staat als Retter. Weinheim: Wiley VCH Verlag.

Singer, Kurt. 1990. Mirror, Sword and Jewel. The Geometry of Japanese Life, 7th ed. Tokyo and New York: Kodansha. Snow, Edgar. 1994. Red Star over China: The Classic Account of the Birth of Chinese Communism. New York: Grove.

Song, Du-Yul, and Rainer Werning. 2012. Korea - Von der Kolonie zum geteilten Land. Wien: Promedia.

Soros, George. 1998. The crisis of global capitalism. The open society endangered. New York: Public Affairs Publisher.

Sünker, Heinz, Russell Farnen, and György Széll (eds.). 2003. Political Socialisation, Participation and Education: Change of Epoch - Processes of Democratisation. Frankfurt: Peter Lang.

Széll, György (ed.). 1972. Privilegierung und Nichtprivilegierung im Bildungswesen. München: Nymphenburger Verlagshandlung.

Széll, György. 1985. Démocratie et Société en 1984 - L'Allemagne, Orwell et Tocqueville. Bulletin de l'Association Internationale des Sociologues de Langue Française 2: 52-69.

Széll, György. 2000. Globalisation in East Asia - A View from Europe. In Globalization in East Asia - Past and Present, ed. Yoshimoto Kawasaki and Shigeto Sonoda, 33-41. Tokyo: Chuô University.

Széll, György. 2001a. Risk \& Reason - or the End of the Age of Enlightenment. In New Democracies and Old Societies in Europe, ed. Széll György and Ehlert Wiking, 63-72. Frankfurt a.M: Peter M. Lang.

Széll, György. 2002. Fifteen Challenges for a European Social Model. In The injustice at Work: An international view on the world of labour and society, ed. Széll György and Cella Gian Primo, 588-606. Frankfurt a.M: Peter M. Lang.

Széll, György (ed.). 2006. Corporate Social Responsibility in the EU \& Japan. Frankfurt a.M: Peter Lang.

Széll, György. 2007. European Union and East-Asian Union - Perspectives of Supra-national Identity in Cross-Cultural Comparison. In Social-Cultural Transformation in the $21^{\text {st }}$ Century - Risks and Challenges of Social Changes, ed. Shigekazu Kusune et al., 169-188. Kanazawa: Kanazawa Electric Publishing Company.

Széll, György. 2008a. Demokratietheorien heute. Sozialwissenschaftliche LiteraturRundschau 31(56-1): 32-38.

Széll, György. 2008b. Soziale Ungleichheit, sozialer Ausschluss durch ungleichen Zugang zu Arbeit - Arbeit als identitä̈sstiftender Wert. In Pädagogik der sozial Ausgeschlossenen, ed. Kock Renate and Günther Henning, 125-142. Frankfurt a.M: Peter Lang.

Széll, György. 2009. 1968 und die Sozialwissenschaften. Hitotsubashi Journal of Social Sciences 41 (2): 59-87.

Széll, György. 2010a. Changing Labour Relations in China. Indian Journal of Industrial Relations 45(4): 554-565.

Széll, György. 2010b. Modernisierung in (Süd-)Korea - Gewalt und Globalisierung. Sozialwissenschaftliche LiteraturRundschau 60: 68-73.

Széll, György. 2010c. Das Ende der Blockkonfrontation. Die Veränderung der Welt nach dem Fall des Eisernen Vorhangs. Osnabrücker Jahrbuch Frieden und Wissenschaft 17: 177-198.

Széll, György. 2011 1a. Law, regulations and actors of social change - The German Sonderweg. In Prawo pracy w śiwetle procesów integracji europejskiej - Księga jubileuszowa Professor Marii Matey-Tyrowicz (Anniversary book in honour of Professor Maria Matey-Tyrowicz), ed. Jerzego Wratnego and Magdaleny B. Rycak, 295-310. Warszawa: LEX-Wolters Kluwer Business.

Széll, György. 201 1b. Die Unvollendete Utopie'- Hochschulreformen und Wissensgesellschaft in Europa. Sozialwissenschaftliche LiteraturRundschau 63: 37-44.

Széll, György. 2013a. Towards A Global Civil Society? In Citizen Participation in Social Welfare, Social Policy and Community Involvement. Shaping trends and attitudes of social responsibility, ed. Litsa Nicolaou-Smokoviti et al., 115-122. Peter Lang: Frankfurt a.M.

Széll, György. 2013b. Germany: Case study on realizing a welfare state as a divided nation and the role of European integration'. In Division and Welfare - Toward a Participatory Peace-Welfare State, ed. Kyung-Hee Institute for Human Society et al., 113-132. Seoul: Imaginepub [in Korean].

Széll, György. 2013c. 'Sozialnationalismus? Anmerkungen zu Wolfgang Streecks „Gekaufte Zeit. Die vertagte Krise des demokratischen Kapitalismus". Sozialwissenschaftliche LiteraturRundschau 67: 39-46.

Széll, György, and Wiking Ehlert. 2001. New Democracies and Old Societies in Europe. Frankfurt a.M: Peter M. Lang. 
Széll, György. 1996. L'État-nation comme système de reliances? In Voyages au coeur des sciences humaines. De la Reliance, ed. Marcel Bolle De Bal, tôme 2, 33-43. Paris: L'Harmattan.

Széll, György, and Dong-Choon Kim (eds.). 2015. Anticommunism in Korea and Germany in Times of Cold War. Seoul: Dolgebae [in Korean].

Széll, György, and Ute Széll (eds.). 2009. Quality of Life \& Working Life in Comparison. Frankfurt a.M: Peter Lang

Széll, György, Carl-Heinrich Bösling, and Ute Széll (eds.). 2008. Education, Labour \& Science - Perspectives for the 21 ${ }^{\text {st }}$ Century. Frankfurt a.M: Peter Lang.

Széll, György, Werner Kamppeter, and Woosik Moon (eds.). 2009. European Social Integration - A Model for East Asia? Frankfurt a.M.: Peter Lang.

Thomas, Rüdiger. 2012. Antikommunismus zwischen Wissenschaft und politischer Bildung. Bonn: Bundeszentrale für politische Bildung.

Thompson, Mark R. 2001. Was ist mit den asiatischen Werten"geschehen? Leviathan 29(2): 218-236.

TNS Opinion \& Social. 2012. The Values of Europeans. Standard Eurobarometer 77. Brussels: Spring.

Transparency International. 2015. Annual report 2014. https:/www.transparency.org/cpi2014/results. Accessed 3 Apr 2015.

Van Waarden, Frans. 1992. Corporatism/Neo-Corporatism. In Concise Encyclopaedia of Participation and Co-Management, ed. Széll György, 193-205. Berlin and New York: de Gruyter.

Vinken, Henk, Joseph Soeters, and Peter Ester (eds.). 2004. Comparing cultures: Dimensions of culture in a comparative perspective. Leiden: Brill Academic Publishers.

von Goethe, Johann Wolfgang. 1827. The sorcerer's apprentice.. http://www.poemofquotes.com/johannwolfganggoethe/ the-sorcerers-apprentice.php. Accessed 1 Apr 2015.

Wagner, Hartmut. 2006. Bezugspunkte europäischer Identität: Territorium, Geschichte, Sprache, Werte, Symbole, Öffentlichkeit. Worauf kann sich das Wir-Gefühl der Europäer beziehen? Münster: Lit-Verlag.

Wallerstein, Immanuel. 2004. The Modern World-System in the Lonque Duree. Boulder/CO: Paradigm Publishers.

Wallerstein, Immanuel. 1974-1989. The Modern World-System: New York: Academic Press, 3 vols.

Walther, Rudolf. 2012. 300 Jahre Europäische Union. Die Zeit.. 6 December: 23.

Weber, Max. 1904. 1991. The Protestant Ethic and the Spirit of Capitalism. London: Harper Collins.

Weber, Max. 1978. Economy and Society: An Outline of Interpretative Sociology. Berkeley/CA: University of California Press. Weggel, Oskar. 1996. Das nachrevolutionäre China. Mit konfuzianischen Spielregeln ins 21. Jahrhundert? Hamburg: Institut für Asienkunde.

Wehler, Hans-Ulrich. 1987-2008. Deutsche Gesellschaftsgeschichte. München: Beck, 5 vols.

Werning, Rainer (ed.). 1988. Südkorea. Köln: Pahl-Rugenstein.

Werning, Rainer. 2002., Nordkorea - Südkorea. Osnabrück: Universität Osnabrück, aepi \# 2.

Wikipedia. 2012a. Dschingis Khan. http://de.wikipedia.org/wiki/Dschingis_Khan. Accessed 9 Dec 2012.

Wikipedia. 2012b. Peace, order, and good government (Canada). http://en.wikipedia.org/wiki/Peace,_order,_and good government. Accessed 9 Dec 2012.

Wikipedia. 2015. Historicism.. http://en.wikipedia.org/wiki/Historicism. Accessed 1 Apr 2015.

Winkler, Heinrich. 2007. Was heißt westliche Wertegemeinschaft? Die ZEIT. 22 February: 12.

Wittfogel, Karl August. 1931. Wirtschaft und Gesellschaft Chinas. Leipzig: Hirschfeld.

World Bank. 1992. ff. Human Development Index. Oxford: Oxford University Press. 